\title{
光ファイバケーブル接続技術 \\ Optical Fiber Splices and Connector
}

\section{1.はじめに}

高度情報化社会の実現に向けて，通信網の光化は必要 不可欠である。経済的かつ信頼性の高い光通信網の構築 には，媒体である光ファイパケーブル技術はもちろん， その接続技術は大变重要である。これまでに様々な光ファ イバケーブル及びその接続技術がその用途に合わせて開 発されてきた。光ファイバケーブルの接続は, メタルケー ブルの接続と異なり，接続する光ファイバ同士の軸方向 の正確な位置合わせが要求される。シングルモード (SM) 型光ファイバのコア径は約 $10 \mu \mathrm{m}$ と微小なため，その 接続には高度な技術が必要である。現在用いられている 主な光ファイバ接続技術は以下の 3 種類である。第一に 融着接続技術。本技術は光ファイバの先端を高温で溶融 し，その先端同士を互いに融着した状態で固定する技術 である。光ファイバ同士を融着で固定するため，再接続 は不可能である。第二にメカニカルスプライス技術。本 技術は V 溝によって光ファイバ同士を位置あわせし， 上下の基盤で光ファイバを挟み込み，固定する技術であ る。本技術も信頼性の钼点から融着接続之同様再接続は 難しい。第三が光コネクタ技術。本技術は光ファイバの 先端に光ファイバ固定用の部品（フェルール）をとりつ け，このフェルール同士を高精度に位置あわせすること により，光ファイバ同士の高精度な接続を実現する技術 である。光コネクタ技術は簡単に再接続が可能であるた め，着脱が頻繁に行われる場所において，ますます多用 される傾向にある。しかし一方で，光コネクタは，価格

\footnotetext{
* 東日本電信電話株式会社 サーピス運営部 技術協力セン夕 東京都品川区東五反田四丁目 10-23 ₹ 141-0022 NIPPON TELEGRAPH AND TEKEPHONE EAST CORPORATION

4-10-23 Higashigotanda, Shinagawa, Tokyo 141-0022 Japan
}

高谷 雅昭 ${ }^{*}$ ・荒川 孝二*

Masaaki TAKAYA and Koji ARAKAWA

や性能の面で他の 2 つ技術に少る。

光コネクタ技術において, 光ファイバに光コネクタフェ ルールを取り付ける際, 多くの光コネクタでは, 接着剤 を用いた固定方法が用いられている。このため, 接着剤 の性能が光コネクタの性能に大きく影響を与える。本稿 では主に光ファイバ接続技術，特に光コネクタ技術に焦 点を当てて，その性能や要求条件について述べる。

\section{2. 光ファイバケーブル技術}

光ファイバケーブルの需要は年々高まりをみせている。 アクセス系での光ファイバケーブル敷設長は, 平成 13

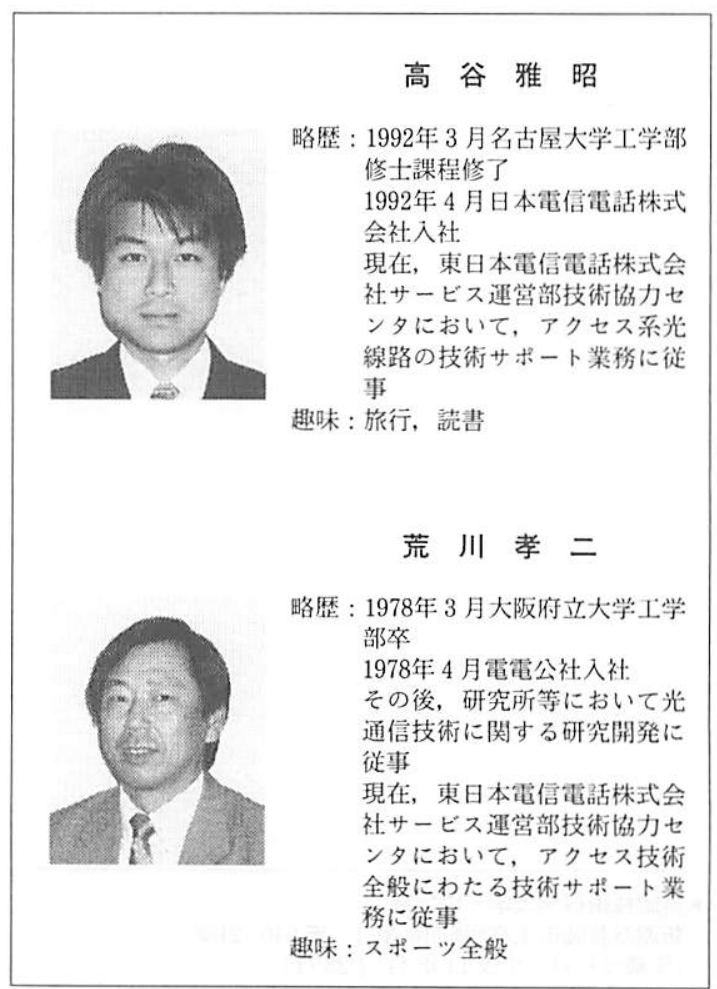




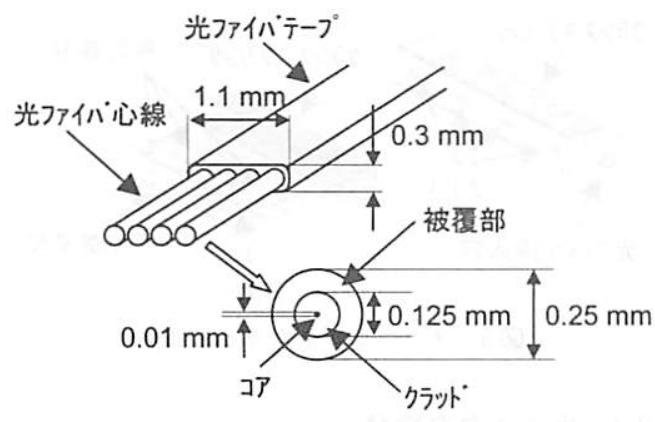

図 1 光ファイバテープの構造

年度で約 24 万 $\mathrm{km}$ となった。これはメタルケーブルと の比較では 5 分の 1 程度であるが, 光ファイバケーブル の敖設長は, 今後む増加㑯向にある。光ファイバケープ ルの構造は様々であるが, 国内における多心光ファイバ ケーブルの構造は, 光ファイバテープを用いたスロット 構造が主流である。ここで, 光ファイパテープとは複数 の光ファイバを一括してテープ化する技術であり, 光ファ イバが $0.25 \mathrm{~mm}$ 間隔で配列されている。図 1 に光ファ イバテープの構造を示す。光ファイバテープの厚さは $0.3 \mathrm{~mm}$ であり, テープ部には紫外線硬化型 (UV) 樹脂 が用いられている。光ケープルを光ファイパテープで設 計することの利点としては, 光ファイパケーブルの高密 度化が可能であること, 心線接続時間を短縮できること, ハンドリング特性を向上できるなどが挙げられる。光ファ イバテープには, 主に 4 心と 8 心が存在し, 4 心テープ は 300 心以下のケーブルに, 8 心テープは 400 心以上の ケーブルに使用されている。

\section{3. ファイバケーブル接続技術}

図 2 に光アクセス網の概略図を示す。図に示すように, 光アクセス網ではその用途に合わせて様々な接続技術が
用いられている。地下系光ファイバケーブル接続には多 心融着接続や多心光コネクタ接続が, 架空光フォイバケー プル接続にはこれらに加えてメカニカルスプライス接続 技術が用いられている。また，局内やビル内など，単心 の光配線が用いられている場所では, 単心の光コネクタ が主に用いられている。

\section{1 接続損失の要因}

同種の SM 型光ファイバ接続時に生じる光損失の主 な要因は以下の 3 点である。第一に光ファイバのコアの 位置ずれ，第二に接続した光ファイバ同士の端面角度， 第三に光ファイバ同士の間隙である。以上の要因によっ て生じる接続損失值 $\mathrm{L}(\mathrm{dB})$ は，以下の式によって導 かれる。

$$
\begin{aligned}
& \mathrm{L}(\mathrm{dB})=-10 \log \left[\frac{16 \cdot \mathrm{n}_{1}^{2} \cdot \mathrm{n}_{0}^{2}}{\left(\mathrm{n}_{1}+\mathrm{n}_{0}\right)^{4}} \cdot \frac{\mathrm{S}}{\mathrm{q}} \exp \left(-\frac{\mathrm{p} \cdot \mathrm{u}}{\mathrm{q}}\right)\right] \\
& \mathrm{p}=\frac{(\mathrm{kg} \cdot \omega \mathrm{t})^{2}}{2} \mathrm{q}=\mathrm{G}^{2}+\frac{(\mathrm{S}+1)^{2}}{4} \mathrm{~F}=\frac{\mathrm{d}}{\mathrm{kg} \cdot \omega \mathrm{t}^{2}} \\
& \mathrm{G}=\frac{\mathrm{z}}{\mathrm{kg} \cdot \omega \mathrm{t}^{2}} \mathrm{~S}=\left(\frac{\omega \mathrm{r}}{\omega \mathrm{t}}\right)^{2} \\
& \mathrm{u}=(\mathrm{S}+1) \cdot \mathrm{F}^{2}+2 \cdot \mathrm{S} \cdot \mathrm{G} \cdot \sin \theta+\mathrm{S} . \\
& \quad\left(\mathrm{G}+\frac{\mathrm{S}+1}{4}\right) \cdot \sin ^{2} \theta
\end{aligned}
$$

ここで, n1, n0 はそれぞれ光ファイバのコアと間隙の 屈折率， $\omega_{\mathrm{t}}, \omega_{\mathrm{r}}$ はそれぞれ出射側，入射側の光ファイ バのモードフィールド径, $\mathrm{d}$ は接続した光ファイバ同士 のコアの位置ずれ量, $\mathrm{z}$ は光ファイバ間の間隙, $\theta$ は接 続した光ファイバの端面角度を表す。これまでの報告か ら, 現在の接続技術における損失の主な要因は光ファイ バコアの位置ずれ量であることが分かっている。そこで, 式 (1) から位置ずれ量以外の要因を取り除くと式 (2) が 得られる。

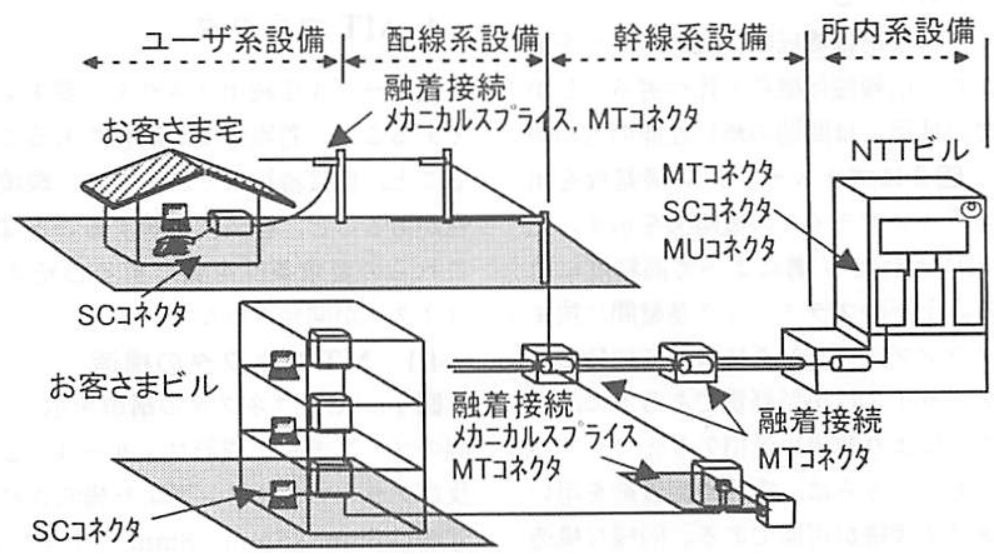

図 2 光アクセス絧における接続技術 


$$
\mathrm{L}(\mathrm{dB})=4.34 \cdot\left(\frac{\mathrm{d}}{\omega}\right)^{2}
$$

接続損失は主に式 (2) によって示される。ただし, 出射 側と入射側のモードフィールド径は同じと仮定した。

\section{2 融着接続}

融着接続技術は光ファイバ同士を物理的に接合させる 技術である。光ファイバは石英ガラスで出来ていること から高温 $\left(2000^{\circ} \mathrm{C}\right.$ 程度) に熱すると先端が乾化する。融 着接続では主に放電によって光ファイバの先端を加熱し， 先端が軟化した状態で両端を付き合わせ，加熱を止める ことで光ファイバ同士の融着を実現している。多心光ファ イバを融着する場合は, 放電の際の電界が一様になる位 置に光ファイバを配列するよう電極の位置と光ファイバ の位置を適切に設計することが必要である。

融着接続において, 光ファイバ同士の位置あわせを行 う方法としては, 光ファイバの外形を基準に調心する方 法と、コアを調心する方法の 2 種類がある。接続損失を 低隇させるにはコアによって調心する方法が優れている。

融着接続技術は，物理的に光ファイバをつなげるため, 信頼性は高い技術である。しかし反面，接続のための機 器が高価であるという欠点が存在する。

\section{3 メカニカルスプライス接続}

メカニカルスプライス技術は, 光ファイバ同士を高精 度に位置古わせし， 2 枚の基盤間に機械的に把持して光 ファイバ同士の接続を実現する技術である。メカニカル スプライスは接続方法が簡単なため, 架空などの悪環境 での作業にも適している。メカニカルスプライスによる 接続は融着接続の場合之同様, 光ファイバのコア位置を 正確に一致させることが重要である。これまでに様々な タイプのメカニカルスプライスが実用化されており, 光 ファイバ同士を高精度に位置合わせする方法としては, 基盤上に V 溝を形成する方法や，ガラスチューブを用 いる方法などが用いられている。

メカニカルスプライス技術は機械的に光ファイバを把 持する技術であるため, 信頼性は融着と比べ劣る。しか し, 現在では屋外での使用には問題の無い性能のものが 実用化されている。図 3 にプラスチック $\mathrm{V}$ 淦基板を用 いた単心用のメカニカルスプライスの概略図を示す。光 ファイバは基盤に形成された V 溝によって高精度に位 置あわせされている。上下のプラスチック基盤間に挟ま れた光ファイバはクランプスプリングによって把持され る。本メカニカルスプライスは小型軽量である上に, 専 用の工具を用いることにより簡単に低損失な光ファイハ の接続が実現可能である。さらに，電源や接着剤を用い ないため，場所を選ばず接続が可能である。同様な構造 で多心のメカニカルスプライスも寒用化されている。

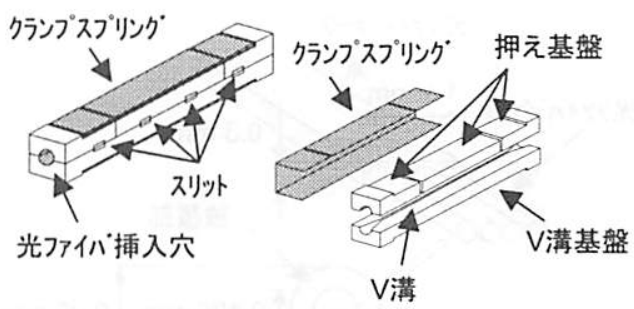

図 3 メカニカルスプライス部品

\section{4 光コネク夕接続}

光ファイバ同士の接続において, 着脱が頻繁に行われ る箇所では光コネク夕技術が有用である。これまでに様々 な光コネクタがその用途に合わせて用いられてきた。局 内やビル内での単心接続には主に FC コネクタや $\mathrm{SC} コ$ ネクタが用いられている。さらに最近では SC コネクタ より小型の MU コネクタや LC コネクタなどむ一般的 に用いられるようになってきた。一方，アクセス系の光 ファイバケーブル接続など多心接続が必要な箇所には MT (Mechanically Transferable) コネクタが用いら れている。最近では装置間通信などでの多心接続が必要 な分野でも，MTコネクタや，MTコネクタの技術を基 に,プッシュープル締結方式で簡易な着脱を可能にした MPO (Multifiber Push-On) コネクタなども用いら れるようになってきた。

光コネクタ技術では, 光ファイバをフェルールに取り 付ける必要がある。本技術では, このフェルールに光ファ イバを高精度に固定し，さらにフェルール同士を高精度 に位置あわせし，高精度な接続を実現している。光ファ イバをフェルールに固定する方法としては，接着剤を用 いる方法が一般的である。ここでは，多心光ファイバケー ブル接続用 MT コネクタを例に, 光コネクタ技術とそ の組立方法とについて説明する。

\section{MT コネクタ}

光ケーブル接続用コネクタの要求条件には, 小型軽量 であること，着脱作業が簡易であること，外力に耐えう ること, 低接続損失であること, 環境に対する長期信頼 性があること, 経済性を有することなどが挙げられる。 これらの要求条件を満たす多心光コネクタとして MT コネクタが開発された。

\subsection{MT コネクタの構造}

図 4にMTコネクタの構造を示す。本コネクタは, 2 個のプラスチック成形フェルール，2 本のガイドピン, 及びクランプスプリングより構成される。フェルールの 寸法は $3 \mathrm{~mm} \times 7 \mathrm{~mm} \times 8 \mathrm{~mm}$ と小型である。フェルール には 2 個のガイドピン穴と, その間に配列した複数の光 


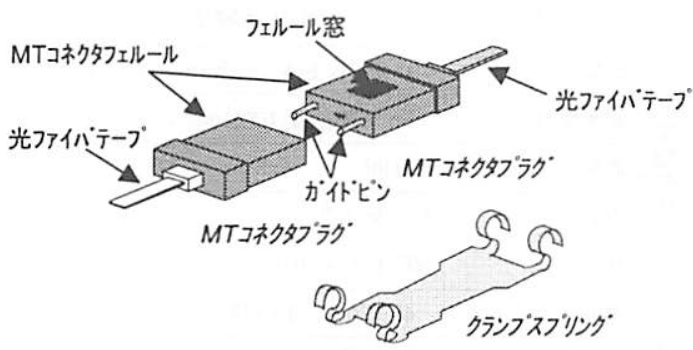

図4 MT コネクタ

ファイバ穴が形成されている。光ファイバは光ファイバ 穴に接着固定されており，その間隔は $0.25 \mathrm{~mm}$ である。 この間隔は現在用いられている光ファイバテープの光ファ イバ間隔に対応している。本コネクタは最大 12 心の光 ファイバ心線を実装することが可能である。接続は，2 本のガイドピンをガイドピン穴に挿入して，フェルール 同士を位置あわせした後, 端面を突き合わせ, クランプ スプリングで締結することによって行う。ここで, 接続 するフェルール端面には予め屈折率整合剤を染布する。 フェルールの切り放しはクランプスプリングを取り外す ことによって行う。このように MT コネクタではコネ クタの接続と切り放しが簡易に行える。

\section{$4.2 \mathrm{MT}$ コネクタの損失}

3.1 で述べたように, 光ファイバ接続時の損失の要因 は, 主に接続する光ファイバ同士のコア位置のずれであ る。光コネクタにおいては, 光ファイバのコア位置のず れ量は, 各コネク夕部品の位置ずれ量の重和合わせによっ て決定される。図 $5 に, M T コ ネ ク タ$ 端面形状と, 各部 品の位置ずれ要因を示す。MTコネクタは, 光ファイバ の位置あわせを 2 本のガイドピンによって行うため, 以 下の 4 点が光ファイバ同士を接続したときの位置ずれ量 の要因となる。

(1) 光ファイバ穴中心の位置ずれ量

(2) 光ファイバ径と光ファイバ穴径のクリアランス量

(3) ガイドピン径とガイド穴径のクリアランス量

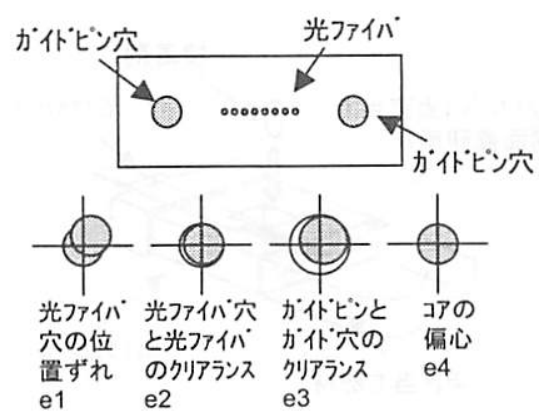

図 $5 \mathrm{MT}$ コネクタの端面形状と位置ずれ要因
(4) 光ファイバのコアの偏心量

これら 4 つの要因が, すべて 2 次元正規分布に従うと 仮定すると，接続した光ファイバ同士の位置ずれ量 $\mathrm{d}$ は, 以下の分布に従う。

$$
f(d)=\frac{d}{2 \cdot \sigma} \exp \left(-\frac{d^{2}}{4 \cdot \sigma^{2}}\right)
$$

ただし, $\mathrm{s}$ は光ファイバの位置ずれ量の標準偏差で, 要 因 (1) （4) の標準偏差をそれぞれ $\sigma 1, \sigma 2, \sigma 3, \sigma 4$ 上する と, $\sigma^{2}=\sigma 1^{2}+\sigma 2^{2}+\sigma 3^{2}+\sigma 4^{2}$ で示される。 式 (2), (3) より光ファイバの接続損失の分布 $g(L)$ は 式 (4) で示される。

$$
g(L)=\frac{1}{\tau} \exp \left(\frac{L}{\tau}\right) \quad\left(\tau=\frac{17.36 \cdot \sigma^{2}}{\omega^{2}}\right)
$$

このとき光コネクタの平均接続損失 $\overline{\mathrm{L}}$ は, 式 (5) で示 される。

$$
\overline{\mathrm{L}}=\frac{17.36 \cdot \sigma^{2}}{\omega^{2}}
$$

MT コネクタでは，各ずれ量を制御することにより，光 ファイバのコアの位置ずれ量を決定し，低損失な光コネ クタを実現している。図 6 に各要因を制御したときの MT コネクタの接続損失を示す。図では, 光ファイバ穴 の位置ずれ量の平均を $0.55 \mu \mathrm{m}$ 以下, ガイドピン穴と ガイドピンのクリアランスを $0.2 \mu \mathrm{m}$ 以下にすることに 上り, 平均光接続損失 $0.2 \mathrm{~dB}$ 以下の低損失コネクタを 得ている。

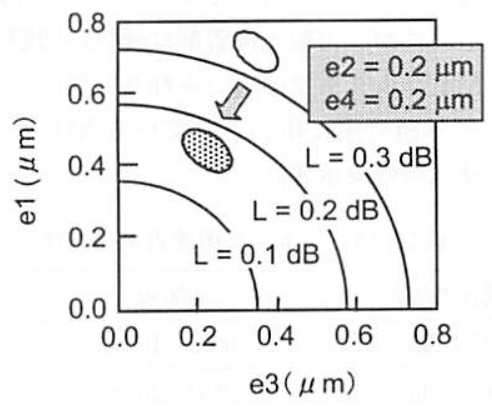

図 6 MT コネクタの接続損失計算結果

\subsection{MT ネクタの組立方法}

$\mathrm{MT}$ コネクタの組み立て方法を以下に示す。まずフェ ルール部品に光ファイバを挿入し、フェルール空から接 着剤を挿入する。フェルール内の空間に接着剤を充填さ せた後フェルールを加熱器によって約 10 分間加熱し 充填した接着剤を硬化させる。その後フェルール端面を 研磨し、端面を平滑にしてMTコネクタプラグが完成 する。図 7 に MT コネクタの内部構造の概略図を示す。 光コネクタフェルールの先端部は, 光ファイバを高精度 


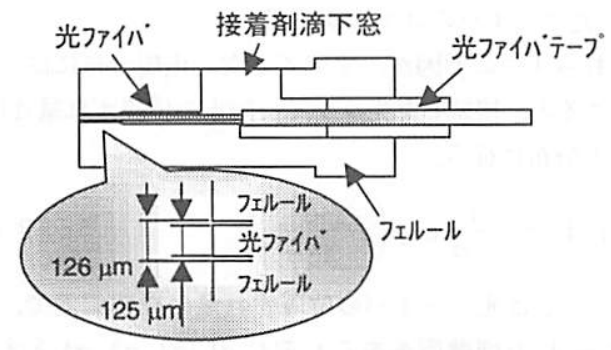

図 $7 \mathrm{MT}$ コネクタの内部構造

に位置あわせするために, 光ファイバ径 $125 \mu \mathrm{m}$ に対し, 直径 $126 \mu \mathrm{m}$ の穴か設けられている。また，後方部には 接着剤を注入するフェルール空の下部に大きな空間が存 在する。高性能の MT コネクタを実現するためには, これらすべての空間に接着剤が充填され, 気泡などが存 在しないことが必要である。MTコネク夕の組立におい て接着剤の取り扱い性は大変重要であり, 以下の条件が 要求される。

(1) コネク夕内の充填を考慮した適切な粘度であること

(2) 作業中に硬化しないこと

(3) フェルールへの滴下後は短時間で硬化すること

(4) 室温での保存が可能なこと

(2) と (3) の条件は相反するものであるが，MTコネク タでは，加熱により迅速に硬化する接着剤を用ることに よってこの問題を解決している。他の光コネクタでは, 熱硬化型の接着剂の他に, UV 硬化接着剤や, 可視光硬 化接着剤なども使用されているが，UV 光の使用は現場 作業での危険性が, 可視光接着片は硬化の問題が存在す るため，MTコネクタでは用いられていない。

表 1 に屋外組立用に用いられている MT コネクタ用 接着剂の基本特性を示す。

表 1 MT コネクタ用接着剤の特性

\begin{tabular}{l|c}
\hline 混合物粘度 & $3000 \mathrm{cp}$ \\
\hline 可便時閣 & $90^{\circ} \mathrm{C} 10$ 分 \\
\hline 硬化時問 & $25^{\circ} \mathrm{C} 20$ 分 \\
\hline ヤング率 & $360 \mathrm{~kg} / \mathrm{mm} 2$ \\
\hline 線膨張係数 & $4.6 \times 10^{-5} \mathrm{~mm} / \mathrm{mm}{ }^{\circ} \mathrm{C}\left(-10^{\circ} \mathrm{C} \sim \mathrm{Tg}\right)$ \\
\hline
\end{tabular}

\subsection{MT コネクタの性能}

$\mathrm{MT}$ コネクタは平均接続損失 $0.2 \mathrm{~dB}$ 以下, 反射減衰 量 $40 \mathrm{~dB}$ 以上という良好な接続特性を有している。さら に, 環境や機械的な負荷に対しても良好な特性を有して いる。表 2 に MT コネクタの信頼性試験項目を示す。 試験項目としては振動, 繰り返し着脱等の機械的試験, ヒートサイクル，温湿度サイクル，高温放置，低温放置
表 2 光コネクタ信頼性試験項目

\begin{tabular}{|c|c|c|}
\hline \multirow{5}{*}{$\begin{array}{l}\text { 環 } \\
\text { 境 } \\
\text { 特 } \\
\text { 性 }\end{array}$} & 耐振性 & $10-55 \mathrm{~Hz}$ 振幅 $0.75 \mathrm{~mm}, 24$ サイクル \\
\hline & 耐衝撃性 & ピーク加速度 $100 \mathrm{G} 6 \mathrm{~ms}$ \\
\hline & 箸脱 & 100 回 \\
\hline & 引張り & 軸方向 $5.9 \mathrm{~N}$ \\
\hline & 曲げ & $90^{\circ} \quad 0.5 \mathrm{~N} 10$ 回 \\
\hline \multirow{4}{*}{$\begin{array}{l}\text { 機 } \\
\text { 械 } \\
\text { 特 } \\
\text { 性 }\end{array}$} & 温度サイクル & $-40-70^{\circ} \mathrm{C}, 4$ 時間, 10 サイクル \\
\hline & 温湿度サイクル & $-10-65^{\circ} \mathrm{C}, 93 \%, 24 \mathrm{~h}, 10$ サイクル \\
\hline & 高温放置 & $70^{\circ} \mathrm{C} 240$ 時䦭 \\
\hline & 低温放置 & $-40^{\circ} \mathrm{C} 240$ 時間 \\
\hline
\end{tabular}

等の環境試験などが挙げられる。温度環境として MT コネクタでは, $-40^{\circ} \mathrm{C}$ から $70^{\circ} \mathrm{C}$ までの温度範囲での性能 を保障することが必要となっている。またここでは挙 げていないが，地下で用いる場合には，水に対する耐久 性む求められる。MTコネクタにおいては, 各試験に対 して実用上問題の無い特性が得られている。これは, MT コネクタに用いた接着片が表に示した環境下でも問 題の無い性能を有することをす示している。

\section{5. これからの接続技術}

今回紹介した MT コネクタに限らず, 光コネクタに 関しては更なる性能の向上や, 組立方法の簡易化, 経済 化が求められている。特に組立作業性の向上に関しては 様々な方法が検討されており，例として，接着剤を用い ずにメカニカル方式で光ファイバを固定する方法や，新 しい接着剤で光ファイバをフェルールに固定する方法な どが挙げられる。新しい接着剤を用いる方法としては, 短時間で硬化する接着剤を用いた組立方法等が検討され ている。図 8 にMTコネク夕の簡易組立技術の一例を 示す。本方式では, まずフェルールに端面を高精度にカッ トした光ファイバを挿入し, 光ファイバ端面をフェルー ル端面に揃える。その後,フェルール慾から高速硬化の 接着剤を充填し, 光ファイバとフェルールを高速に固定

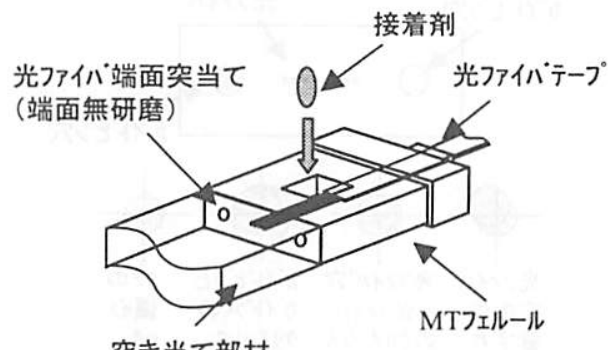

突き当て部材

図 $8 \mathrm{MT}$ コネク夕簡易組立技術 
する。この方式では, 従来の MTコネク夕の組立方法 と異なり, 接着風の加熱工程と研磨工程が省略でき, 大 幅な作業時間の短縮と工具の簡易化を図ることが可能と なる。ただし,フェルールと光ファイバの間隙に均一に 接着剤を充填する方法や, 高速硬化型接着斉の耐環境特 性問題など解決されていない課題が数多く存在するため, 本方式は実用にはいたっていない。

\section{6. まとめ}

高度情報化社会の実現に向けて, 光ファイバ網を構筑 することは大变重要である。光ファイバ網には様々な接 続ポイントが存在するため, 光ファイバの接続技術は必 要不可欠である。接続技術の中であ光コネクタ技術は, 着脱が必要な箅所においてはますます重要になっている。
現在用いられている光コネクタに対しては, 経済化なよ゙ の面から，より組立方法が簡単なものが必要となってお り, その際には, 新しい接着剤が必要不可欠である。ま た，接着闵を用いた新しい接続方法も提案されており， 今後光ファイパケーブル接続技術の分野で, 接着剤技術 はますます重要になると考えられる。

\section{文献}

1) D. Marcuse, The Bell System Technical Journal, 56, No. 5, 703 (1977)

2) M. Takaya, T. Katagiri, S. Nagasawa, Y. Murakami, S. Hatano, IEEE Transactions on Components, Packaging, and Manufacturing, 23, No. 1, 36 (2000)

3) K. Shibata, M. Takaya, S. Nagasawa, IEEE Photn. Tecnol. Lett., 13, No. 2, 136 (2001)

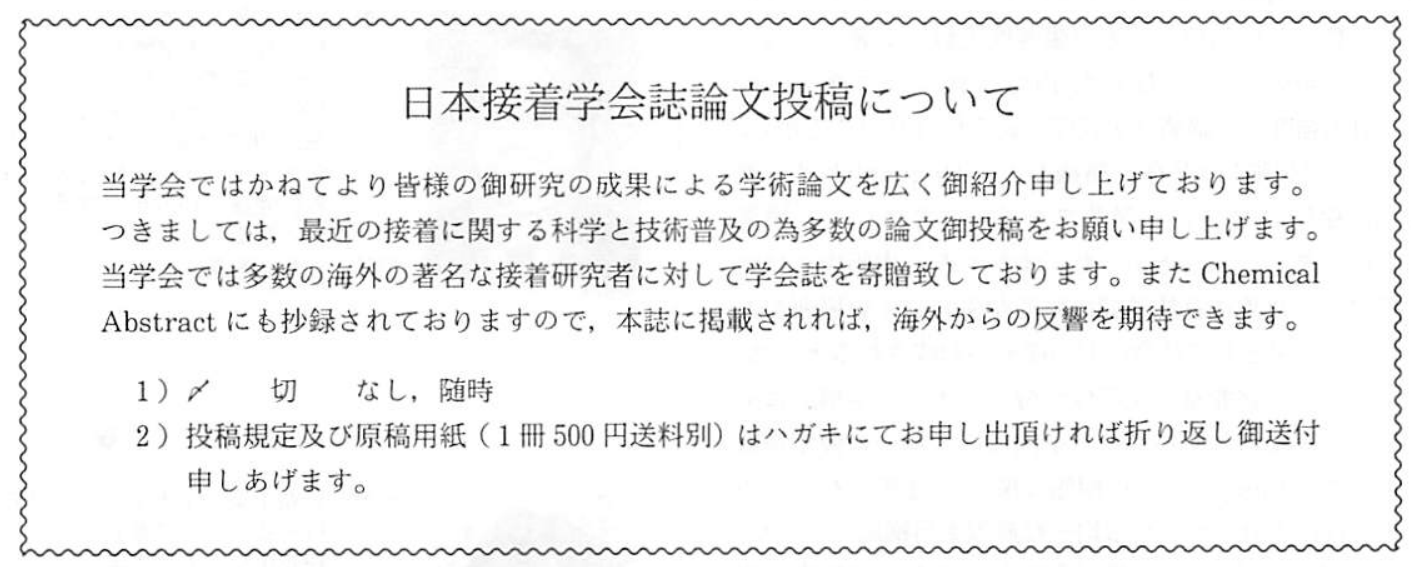

